\title{
A Green Roof Test Bed for Stormwater Management and Reduction of Urban Heat Island Effect in Singapore
}

\author{
Xiaosheng Qin ${ }^{1,2^{*}}$, Xiangyu $\mathrm{Wu}^{3}$, Yee-Meng Chiew ${ }^{1}$ and Yanhong $\mathrm{Li}^{3}$ \\ ${ }^{1}$ School of Civil and Environmental Engineering, Nanyang Technological University, \\ Singapore. \\ ${ }^{2}$ Earth Observatory of Singapore, Nanyang Technological University, Singapore. \\ ${ }^{3}$ Energy Research Institute, Nanyang Technological University, Singapore.
}

\begin{abstract}
Authors' contributions
This work was carried out in collaboration between all authors. Author XQ designed the green roof system and wrote the manuscript while author YMC provided assistance in improving it. Authors XW and YL managed the data collection and equipment maintenance. All authors read and approved the final manuscript.
\end{abstract}

Research Article

Received $3^{\text {rd }}$ December 2012

Accepted $7^{\text {th }}$ January 2013

Published $19^{\text {th }}$ January 2013

\section{ABSTRACT}

A green roof test bed, established at the Nanyang Technological University in Singapore, was used to investigate its benefit for storm water management and urban heat island effect mitigation. The system comprised 3 units, 2 in the form of vegetated roofs and the other a bare roof. The system was equipped with automatic monitoring devices for measuring the hydrological data. Continuous data monitoring on the roofs was conducted to evaluate the thermal and hydrological effects. The study shows that the green roof test bed can significantly reduce the roof surface temperature (by an average of $7.3^{\circ} \mathrm{C}$ ) and lower the ambient air temperature (by an average of $0.5^{\circ} \mathrm{C}$ ) when compared with a bare roof during day time hours (from 10:00 am to 4:00 pm). The ability to reduce and delay the peak runoff was demonstrated by using a typical rainfall event with $18 \mathrm{~mm}$ depth. The designed system is useful in evaluating both thermal and hydrological benefits of a green roof system in tropical areas and can offer guidance to local managers in mitigating the urban heat island effect and designing storm water management strategies.

\footnotetext{
*Corresponding author: Email: xsqin@ntu.edu.sg;
} 
Keywords: Green roof; climate change; hydrology; runoff; heat island effect.

\section{INTRODUCTION}

Singapore is a high-income city-state with a population of over 5 million and a land area of about $700 \mathrm{~km}^{2}$. Extensive urbanization over the years not only has caused a considerable reduction in green areas in the country but also led to the increase of storm water runoff and peak flow rates, aggravating the risk of flooding. Arising from the changing climatic conditions, the occurrence of extreme rainfall is expected to rise [1]. The adverse environmental impact on Singapore when subjected to these changes is the escalated urban heat island $(\mathrm{UHI})$ effect and the associated increased in energy consumption for cooling.

A green roof, as a 'carpet' of plants on the roof of buildings, offers many benefits in addition to enhancing its aesthetic value. The primary benefit is its thermal insulation potential. A green roof can greatly enhance heat resistance against a heat flux through the roof, which significantly reduces the energy consumption for cooling the building. It could also reduce the urban heat island ( $\mathrm{UHI}$ ) effect due to heat absorption, shading, and evapotranspiration [2-6]. The other major benefit is its ability to delay the storm runoff peak occurrence, thus reducing the peak flow rate and mitigating flood risks [7-8]. In summary, for a tropical city like Singapore, it could potentially reduce the adverse effect of climate change by reducing cooling needs and shifting runoff peaks, thus offering a more favorable environmental quality.

There are many studies related to the thermal benefit of green roof systems [9-12]. More specifically, Weng et al. [13] analyzed the relationship between the land surface temperature and vegetation for UHI studies. Liu and Minor [14] evaluated the thermal performance and energy efficiency of two extensive green roof systems installed on a community centre in Toronto. Their results showed that the daily maximum temperature of the roof material could drop by $30-40^{\circ} \mathrm{C}$ by installing a green roof system. Takebayashi et al. [15] investigated the surface temperature, net radiation, water content etc. of green roofs and high reflection roofs to reveal green roof's performance in mitigating UHI. Fang [16] investigated the thermalreduction effect of green roof's plant layers and revealed that the coverage ratio and total leaf thickness were related to the capacity of thermal reduction.

The experimental studies on the hydrological aspect of green roof were also widely reported [17]. VanWoert et al. [18] investigated the effect of vegetation types, substrates and slope on storm water retention of green roofs. Carter and Rasmussen [19] developed a green roof and a black roof test system at the University of Georgia; their study indicated that green roof precipitation retention is around $90 \%$ for small storms and $50 \%$ for larger storms. Teemusk and Mander [20] investigated the storm water retention capacity and runoff water quality of a green roof system in Estonia. The study showed that $85.7 \%$ of light rain could be retained and the runoff peak of a heavy rainstorm could be delayed by half an hour although the runoff cannot be fully retained. Hathaway et al. [21] investigated the hydrologic and water quality performance of two green roofs in eastern North Carolina's Neuse River Basin. More than $75 \%$ reductions of the average peak flow were observed from each green roof in the study. In presenting the monitoring results from a field-scale living roof in New Zealand, Voyde et al. [22] reported that an average of $82 \%$ of rainfall amount could be retained, and about $93 \%$ peak flow could be reduced. Based on an extensive set of rainfall-runoff data (covering 29 month) from a green roof test bed in United Kingdom, Stovin et al. [23] concluded that the roof could provide $50.2 \%$ cumulative annual rainfall retention. All these studies have shown that green roofs could significantly contribute to the attenuation of rainstorm flooding risks. 
In Singapore, however, few studies have been carried out to investigate the UHI effect and hydrological assessment of green roofs. This study aims to report a pilot-scale green roof test bed that was established at Nanyang Technological University (NTU) in Singapore for a preliminary study of storm water management and reduction of $\mathrm{UHI}$ effect. The system is equipped with automatic monitoring devices and thus requires minimum maintenance. The emphasis of the study is placed on investigating the thermal and hydrological benefit that a green roof can bring in a tropical climate. The results from this monitoring work may provide an essential data support for an in-depth hydrological modeling study in the future.

\section{MATERIALS AND METHODS}

\subsection{Test Bed Descriptions}

The green roof test bed, which is located on top of Academic Complex N1, NTU, Singapore (Fig. 1), comprises 3 independent units; each with a dimension of $2 \mathrm{~m} \times 2 \mathrm{~m}$. Two of the units (Units 1 and 2) are filled with soil and plants and thus function as green roofs. The third (Unit 3) unit is the control with only bricks laid on it. Each unit consists of four $1 \mathrm{~m} \times 1 \mathrm{~m}$ planter boxes, with three inter-connecting parts: (1) an open top tray, (2) a bottom filtration tray, and (3) a base frame. The reason for having a planter-box design is to ease the assembling and dissembling activities. In order to simulate different roof angles, each unit is hinged at one end so that the angle of the roof can be adjusted from $0^{\circ}$ to $15^{\circ}$ (shown by an indicator attached to the main structure). In this study, the angle is set at $5^{\circ}$.

Fig. 2 shows how the planter box is filled with $25-\mathrm{cm}$ depth of soil with grass and flowers (Cuphea with grass) planted therein. A $5 \mathrm{~cm}$ thick bottom filtration tray (filled with pebbles and is separated from the soil by a mesh layer and a filter layer) is designed to allow water to drain. Two water collection tanks are used to collect water from both the surface runoff (including overland flow and interflow) and baseflow (including percolated water). Each green roof unit is elevated by about $40 \mathrm{~cm}$ from the ground to allow sufficient height for the conduct of flow rate measurement.

In order to obtain enough information to evaluate the performance of the green roof, the test bed is designed to collect meteorological, hydrological and thermodynamic data including air and soil temperature; wind speed, radiation, air moisture; rainfall and runoff (Table 1). The measurement system consists of three major components:

1) Wireless auto weather station. The weather information, including wind speed and direction, radiation, temperature, relative humidity and rainfall is logged and transmitted remotely to a web server, which can be accessed through the internet (HOBOLINK). The system was self-supported with a 6-W solar panel. 


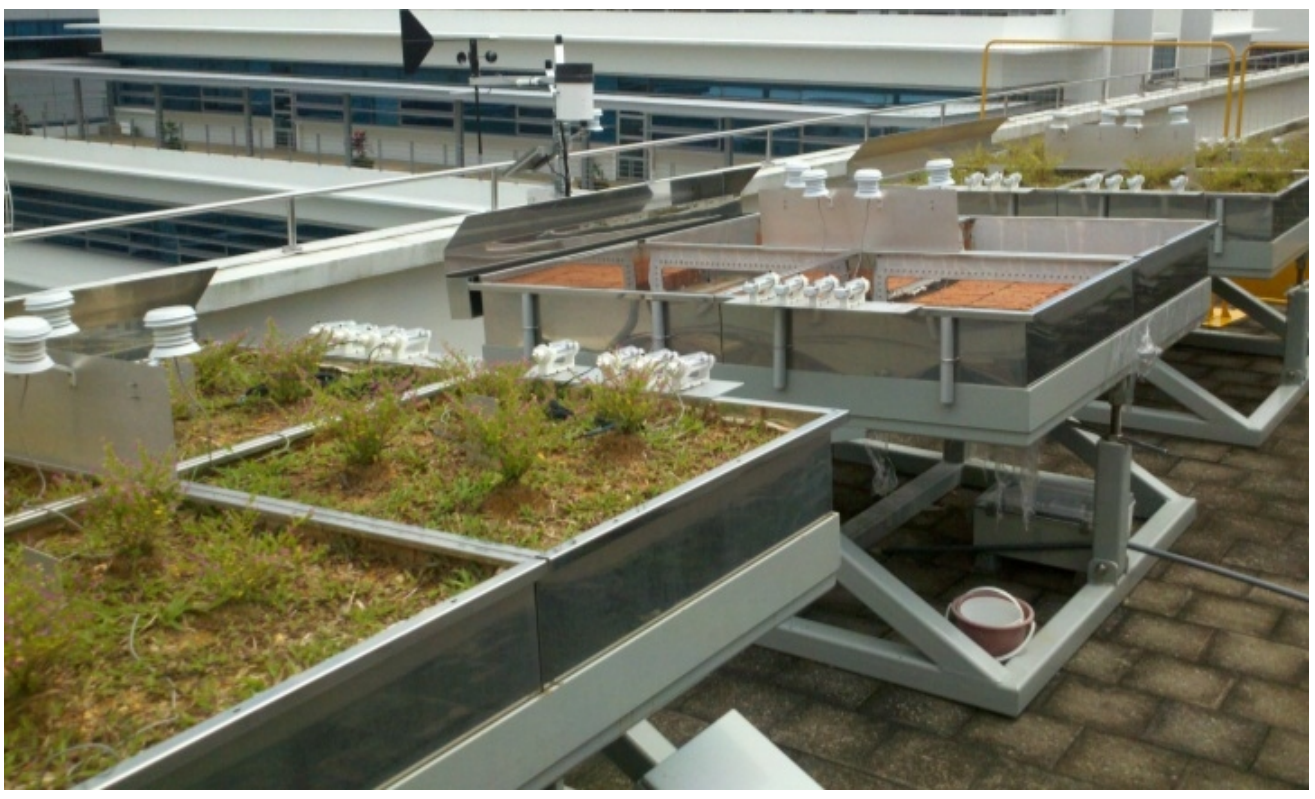

Fig. 1. Green roof test bed on the roof of academic complex N1 in NTU

Three units of planter boxes are deployed; the middle one is the bare roof control.

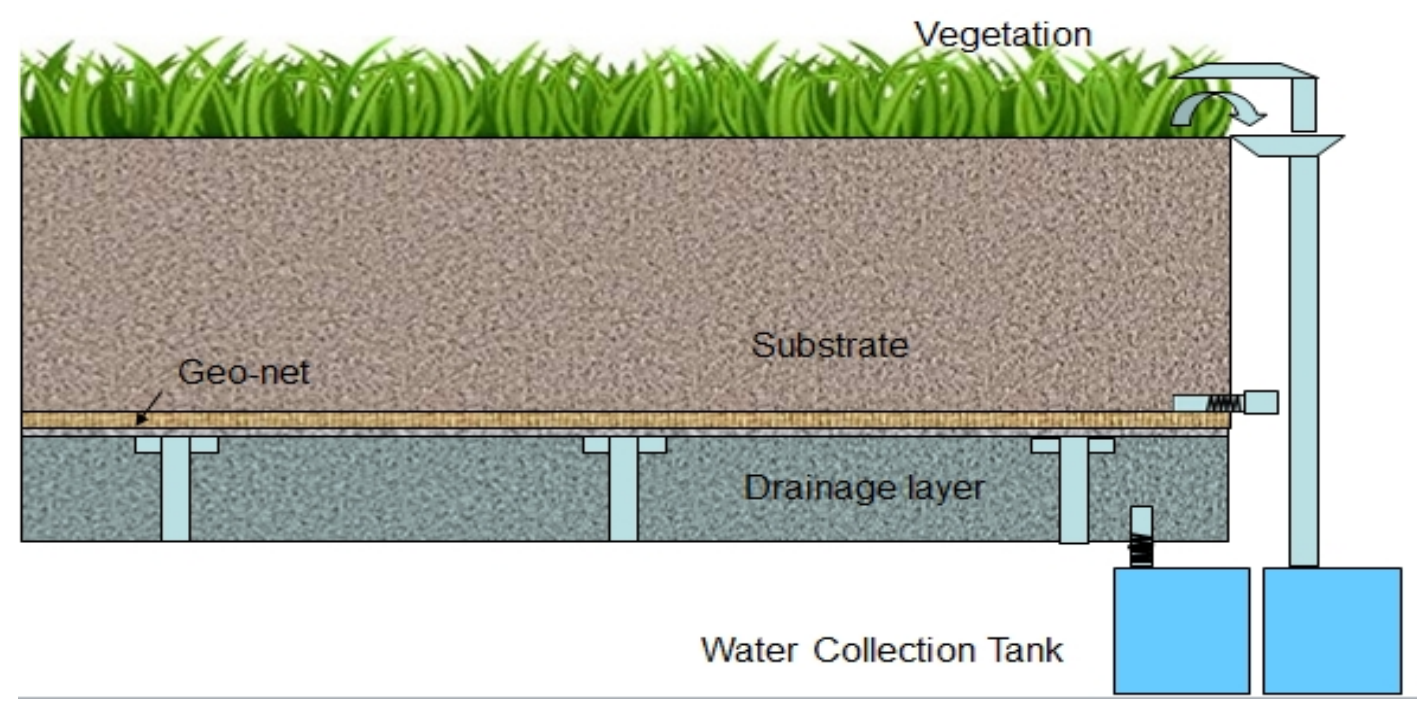

Fig. 2. Green roof section

2) Temperature monitoring. To compare the environmental behaviour between the green and bare roof, the temperature information at various locations in the test bed is collected. In the bare roof, two temperature sensors are placed, with one located at about $0.3 \mathrm{~m}$ above the brick level and the other just on the surface. For each green roof unit, four temperature sensors are installed; they are located at (i) $0.3 \mathrm{~m}$ above the soil surface; (ii) the top level (50 $\pm 2 \mathrm{~mm}$ below soil surface); (iii) the middle level ( $100 \pm 2 \mathrm{~mm}$ below soil surface); and (iv) the lower level $(150 \pm 2 \mathrm{~mm}$ below soil surface). Fig. 3 shows the detailed locations of the 
sensors. The temperature data are transmitted to a computer located in a nearby office via a signal repeater and a receiver. This is to prevent signal interference by the surrounding buildings. The sensor reading time interval is 0.5 seconds.

3) Water level monitoring. The water level monitoring system relies on an external power supply to ensure continuous and uninterrupted operation. The water level sensor, which was held on top of the water collection tank, detects the water level in the tank. The water level sensor is a sonar system with a resolution of $0.01 \mathrm{~mm}$. The real time data are retrieved from data loggers using a USB disk.

Table 1. Data summary

\begin{tabular}{lll}
\hline System & Data to be measured & Variable type \\
\hline HOBO weather station & $\begin{array}{l}\text { Wind speed } \\
\text { temperature } \\
\text { Radiation }\end{array}$ & Meteorological \\
& $\begin{array}{l}\text { Rain } \\
\text { Soil temperature } \\
\text { Air temperature } \\
\text { Wir \& soil temperature monitoring }\end{array}$ & Thermodynamic \\
Water level monitoring (OMRON data logger) & Hydrological \\
\hline
\end{tabular}

- Above Air Temp

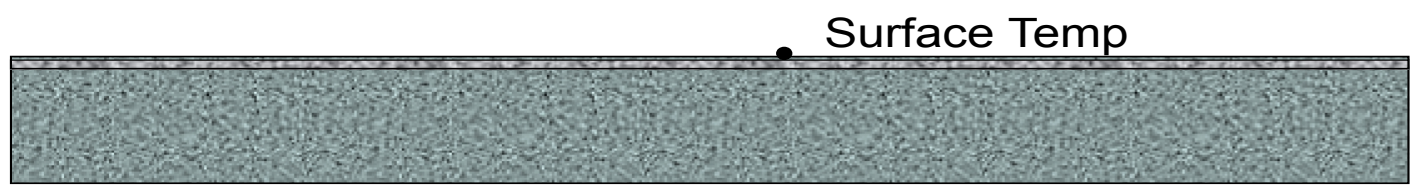

- Above Air Temp

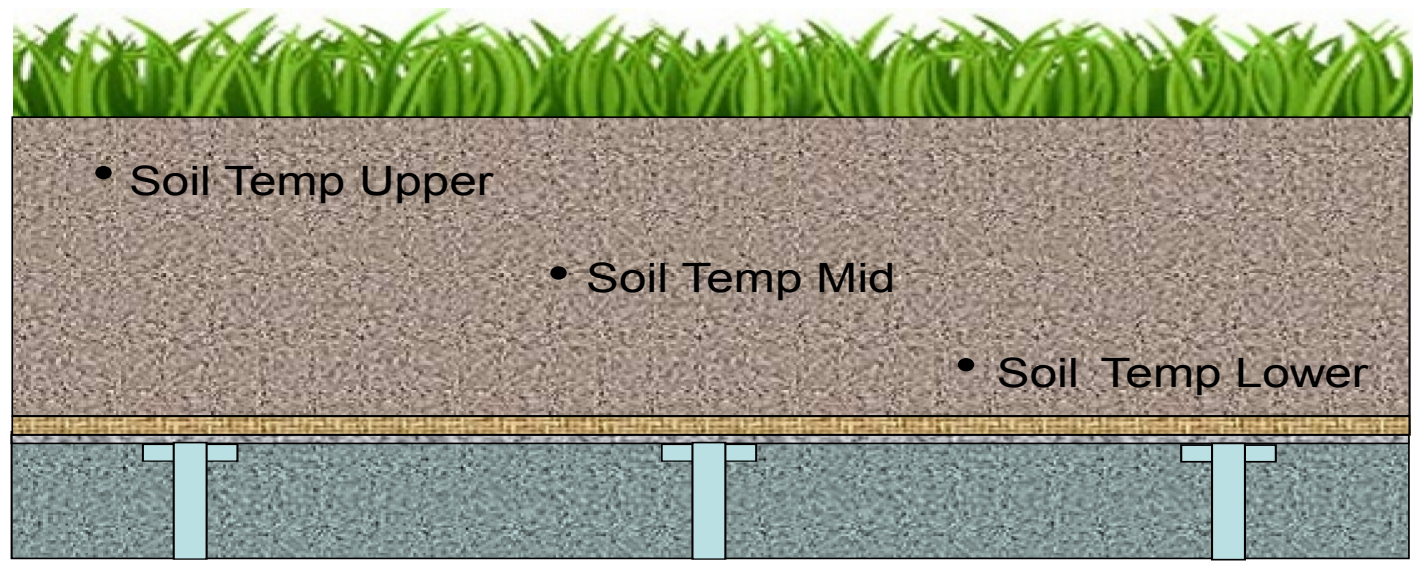

Fig. 3. Location of temperature sensors

Upper figure - bare roof; bottom figure - green roof. 


\subsection{Design of Water Collection Tank}

In a hydrological system, the total stream flow can be categorized into three parts: surface runoff, interflow and infiltrated water. The interflow is the portion of water that moves laterally in the subsurface. In this study, the surface runoff and interflow are collected in the same water collection tank and the infiltrated flow (hereinafter called base flow) is collected in another tank. The size of the outlet is the key to a successful measurement. As the flow rate is significantly less than a natural stream flow, a normal V-notch or sharp-crested weir is inappropriate for use. In order to control the water level to a reasonable height for sonic detection, the outlet of the water collection tank is designed as a circular orifice. The diameter is estimated based on the following orifice equation [24]:

$$
Q=\zeta A \sqrt{2 g h}=\zeta \pi r^{2} \sqrt{2 g h}
$$

where $Q$ is the flow rate $\left(\mathrm{m}^{3} / \mathrm{s}\right) ; \zeta$ is the hydraulic coefficient; $g$ is the gravitational acceleration $\left(\mathrm{m} / \mathrm{s}^{2}\right)$; $h$ is the water head $(\mathrm{m})$; $A$ is cross sectional area of the outlet pipe $=$ $\pi r^{2}\left(\mathrm{~m}^{2}\right)$; and $\mathrm{r}$ is the outlet radius $(\mathrm{m})$.

The design is based on a relatively high hourly rainfall rate of around $115 \mathrm{~mm} /$ hour in Singapore [25]. The equivalent flow rate is about $1.278 \times 10^{-4} \mathrm{~m}^{3} / \mathrm{s}$. A water level sensor with a detection range is from $5 \mathrm{~cm}$ to $30 \mathrm{~cm}$ is placed on top of the stainless water collection tank. The designed maximum water head is around $200 \mathrm{~mm}$, which corresponds to an orifice diameter of around $12 \mathrm{~mm}$. However, considering the rainfall rate will be lower than the maximum value most of the time, three orifices with different diameters $(4 \mathrm{~mm}, 6 \mathrm{~mm}, 9 \mathrm{~mm})$ are drilled on the façade of the collection tank (Fig. 4). The orifice is about $3 \mathrm{~cm}$ above the bottom from the center. The hydraulic coefficient, $\zeta$ of each orifice is determined by fitting the equation to actual site data.

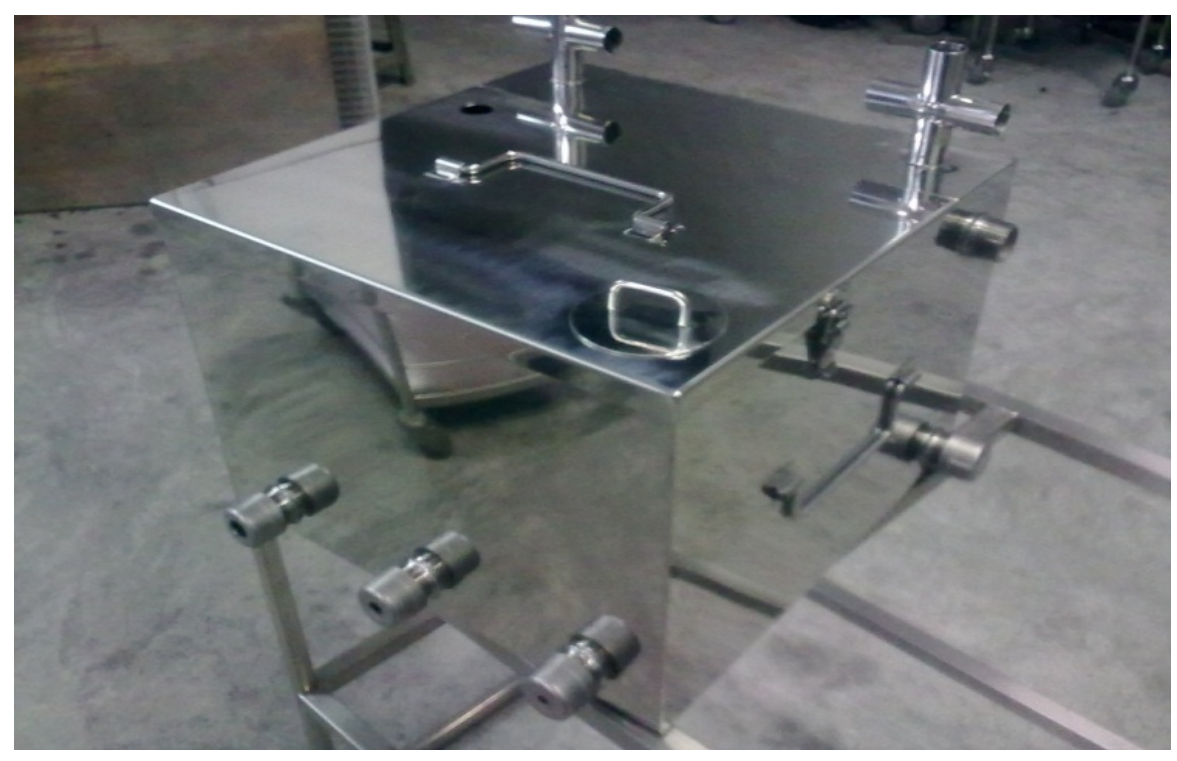

Fig. 4. Water collection tank 
The interflow can flow naturally through the soil media in the four planter boxes and exit through the six holes drilled at the lower side wall of the green roof unit. The overland runoff (i.e. overflowing water) is diverted directly to a collection tray before combining with the interflow and drain to the water collection tank. Meanwhile, the 5-cm bottom filtration tray enables the percolated water to be drained to another water collection tank via flexible pipes attached to three holes drilled on the bottom of the roof unit.

\section{RESULTS AND DISCUSSION}

The experiments started from June 25, 2012 and are expected to last for 2 years. Calibration and adjustment of the system was conducted regularly. Fig. 5 shows a snapshot of a 1-week weather data from November 27 to December 3, 2012. The temperature generally ranges from 24 to 34 degrees and the relative humidity from $60 \%$ to $100 \%$. Solar radiation and wind speed are somewhat consistent with the temperature profiles. Generally, the weather station effectively reflects the regional weather condition at the study area.

From June 2012, all temperature data were collected except for the periodic downtime for checking (less than 30 minutes each week). The continuous temperature data for the green roof and bare roof shows different variation trends. One typical 5-days temperature data (from Aug. 09, 2012 00:00 to Aug.13, 2012 23:59) is shown in Fig. 6. For the green roof, the air temperature value is the average of the two measured air temperatures over planter box units 1 and 2 . The soil temperature profiles are from planter box 1 .
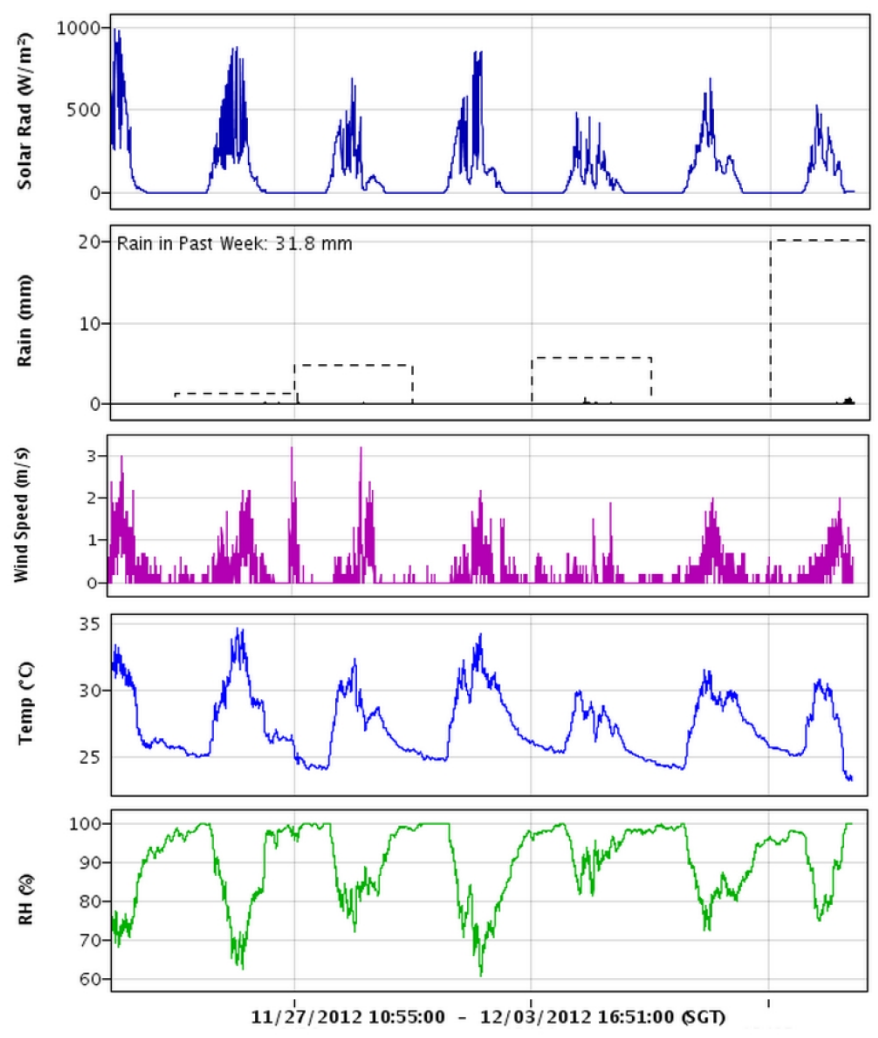

Fig. 5. Weather station data from Nov. 27, 2012 to Dec. 3, 2012 
(a) Bare Roof Temperature Trends
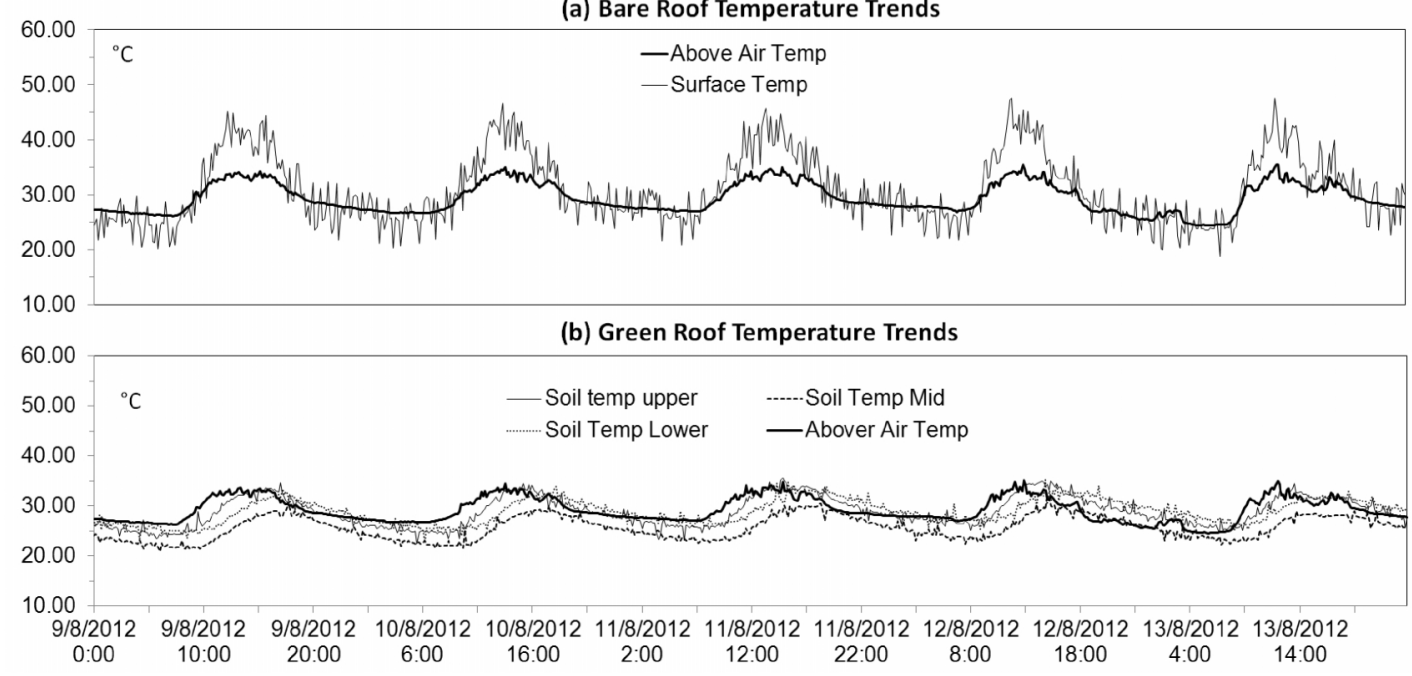

Fig. 6. Temperature profiles from Aug. 09, 2012 to Aug.13, 2012

Fig. 6 shows that the green roof system has a much better thermal performance in the day, especially from 10:30 am to $6: 00 \mathrm{pm}$, having a relatively stable temperature profile and only experience a slight fluctuation between the day and night time temperature. Meanwhile, the surface temperature of the bare roof exhibits a more significant daily variation. For example, the average surface temperature difference of the bare and green roof from 10:00 am to 4:00 pm is about $7.3^{\circ} \mathrm{C}$. The maximum difference observed is about $15.3^{\circ} \mathrm{C}$. The air temperature above the green roof is slightly lower than that above the bare roof during sunlight hours, but the former is almost equal to (or slightly higher than) the latter at night. For example, the average air temperature difference of the bare and green roof from 10:00 am to $4: 00 \mathrm{pm}$ is about $0.5^{\circ} \mathrm{C}$. The maximum difference observed is about $1.3^{\circ} \mathrm{C}$. This result reveals a promising cooling and a potential UHI mitigation effect by using green roof systems on buildings.

During the test period from June to November 2012, more than 30 individual rainfall events were recorded. However, due to water level sensor problems during high rainfall events, only a limited number of runoff events were successfully captured during this period. The available data show that the green roof offer different levels of retention capacity and peak flow mitigation. For example, the rainfall event on September 27, 2012, which is shown in Fig. 7 , reveals that the rain lasts for 1.5 hours, with a total depth of around $18 \mathrm{~mm}$ and maximum intensity $=1 \mathrm{~mm} / \mathrm{min}$. The data also show that the infiltrated flow, surface runoff, and retained water are $8.5,5.6$, and $3.9 \mathrm{~mm}$, respectively. The figure also indicates that the volume and peak flow rates of the runoff is different between the green and bare roof systems. The peak flow is reduced by $65 \%$ by the vegetated roof and the overall runoff is retained by about $11.4 \%$. Moreover, the peak runoff rate has been slighted delayed by about 3 minutes. Based on the results from other rains, it was found that the retention capacity of green roof has notable variations, and is affected by rain frequency, intensity and antecedent dry days. Fig. 7 also shows that the surface runoff plays a less significant role than the base flow in affecting the overall runoff. This may be because the drainage layer is filled with pebbles and has a much higher hydraulic conductivity, and thus the water flowing through this channel responds faster to the rainfall variations. Another reason may be the more 
unfavorable water passage ways on the wall (due to longer travel distance) than those at the bottom.

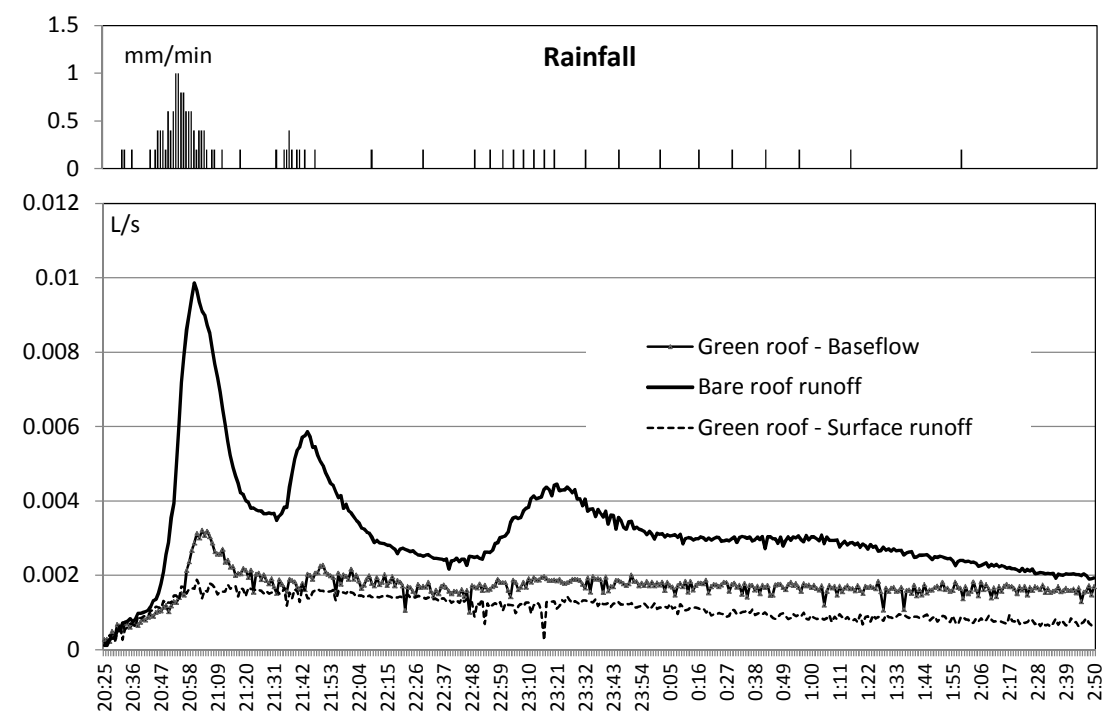

Fig. 7. Rainfall-runoff on September 27, 2012

Singapore is characterized by tropical climate with no significant seasonal changes (NEA, 2012). The annual average rainfall is around $2,400 \mathrm{~mm}$ and the temperature has a diurnal range of 23 to $34^{\circ} \mathrm{C}$. These numbers may be influenced by climate change in the future. $A$ rising temperature means that the city buildings will require more air conditioning and higher energy usage than the present; the heat generated there from will exacerbate the heat island effect. Based on results of the present study, the green roof system is effective in reducing the surface temperature of building tops as well as providing direct cooling effect on the surrounding air, mainly due to increased evapotranspiration from both the soil and plants. The establishment of green roof systems will be a viable alternative for mitigating the UHI effect that is envisioned to be more serious in the future. City managers could also consider incorporating green roofs as one of the adaptation strategies for improving local hydrology and storm water management, particularly for those intensely urbanized areas, such as downtown, business parks or industrial complexes. For example, the urban flooding problems have frequently been reported at the Orchard Road area in Singapore where more than one third of the area is occupied by commercial buildings. If more than $80 \%$ of the buildings are furnished with a green roof (provided that the substrate is the same as the test bed and the average rainfall intensity is similar to that in Fig. 5), the peak runoff could be reduced by about $17 \%$. Of course, a more accurate number needs to be determined by more rigorous hydrological studies.

\section{CONCLUSIONS}

A green roof test bed, established at NTU, Singapore, was reported in this study. The system is equipped with automatic monitoring devices that require minimum maintenance. $A$ continuous data monitoring on the green roof was conducted to investigate its thermal and hydrological effects. The study reveals that green roofs could significantly reduce the surface 
temperature (by $7.3^{\circ} \mathrm{C}$ ) and somewhat lower the ambient air temperature (by $0.5^{\circ} \mathrm{C}$ ) compared with a bare roof during the day (from 10:00 am to 4:00 pm). For a typical rainfall event with maximum intensity $=1 \mathrm{~mm} / \mathrm{min}$, the green roof is effective in reducing the peak flow by $65 \%$ and retaining the overall runoff by $11.4 \%$. The designed system is useful in evaluating the cooling effect and the hydrological benefit of green roof systems and offer guidance to local managers in mitigating urban heat island effects and designing storm water management strategies. In future studies, more statistical significant analysis will be given based on a longer continuous monitoring effort.

\section{ACKNOWLEDGEMENTS}

This project is supported by College of Engineering Central Fund (M4060144.030) and Energy Research Institute (ERI@N), Nanyang Technological University, Singapore.

\section{COMPETING INTERESTS}

We declare that no competing interests exist for this paper.

\section{REFERENCES}

1. Allen MR, Ingram WJ. Constraints on future changes in climate and the hydrologic cycle. Nature. 2002;419:224-232. DOI:10.1038/nature01092

2. Onmura S, Matsumoto M, Hokoi S. Study on evaporative cooling effect of roof lawn gardens. Energy and Building. 2001;33(7):653-666. DOI:10.1016/S03787788(00)0013 4-1

3. Wong $\mathrm{NH}$, Chen $\mathrm{Y}$, Ong $\mathrm{CL}$, Sia A. Investigation of thermal benefits of rooftop garden in the tropical environment. Building Environment. 2003;38(2):261-270. DOI:10.1016/ S0360-1323(02)00066-5

4. Alexandri $E$, Jones $P$. Temperature decreases in an urban canyon due to green walls and green roofs in diverse climates. Building and Environment. 2008;43(4):480-493. DOI: 10.1016/j.buildenv.2006.10.055

5. Teemusk A, Mander Ü. Greenroof potential to reduce temperature fluctuations of a roof membrane: a case study from Estonia. Building Environment. 2009;44(3):643650. DOI: 10.1016/j.buildenv.2008.05.011

6. Metselaar K. Water retention and evapotranspiration of green roofs and possible natural vegetation types. Resources, Conservation and Recycling. 2012;64:49-55. DOI: 10.1016/j.resconrec.2011.12.009

7. Carter T, Jackson CR. Vegetated roofs for stormwater management at multiple spatial scales. Landscape Urban Planning. 2007;80(1-2):84-94. DOI:10.1016/j.landurbplan.20 06.06.005

8. Kasmin H, Stovin VR, Hathway EA. Towards a generic rainfall-runoff model for green roofs. Water Science \& Technology. 2010;62(4):898-905. DOI:10.2166/wst.2010.352

9. Lee DO. Urban warming? - An analysis of recent trends in London's heat island. Weather. 1992;47(2):50-56. DOI:10.1002/j.1477-8696.1992.tb05773.x

10. Streutker DR. Satellite-measured growth of the urban heat island of Houston, Texas. Remote Sensing of Environment. 2003;85(3):282-289. DOI:10.1016/S0034-4257(03)0 0007-5

11. Rosenzweig C, Solecki WD, Parshall L, Chopping M, Pope G, Goldberg R. Characterizing the urban heat island in current and future climates in New Jersey. Environmental Hazards. 2005;6(1):51-62. DOI:10.1016/j.hazards.2004.12.001 
12. Xie HJ, Chang NB, Daranpob A, Prado D. Assessing the Long-term Urban Heat Island in San Antonio, Texas based on MODIS/Aqua Data. $20^{\text {th }}$ Biennial Workshop on Aerial Photography, Videography, and High Resolution Digital Imagery for Resource Assessment, Oct. 4-6, 2005, Weslaco, Texas; 2005.

13. Weng Q, Lu D, Schubring J. Estimation of land surface temperature-vegetation abundance relationship for urban heat island studies. Remote Sensing of Environment. 2004;89(4):467-483. DOI:10.1016/j.rse.2003.11.005

14. Liu K, Minor J. Performance evaluation of an extensive green roof. Paper presented at the Third Annual Greening Rooftops for Sustainable Communities Conference, Awards and Trade Show; 4-6 May 2005, Washington, DC; 2005.

15. Takebayashi H, Moriyama M. Surface heat budget on green roof and high reflection roof for mitigation of urban heat island. Building and Environment. 2007;42:2971-2979.

16. Fang CF. Evaluating the thermal reduction effect of plant layers on rooftops. Energy and Buildings. 2008;40(6):1048-1052. DOI:10.1016/j.enbuild.2007.06.007

17. Mentens J, Raes D, Hermy M. Green roofs as a tool for solving the rainwater runoff problem in the urbanized $21^{\text {st }}$ century. Landscape and Urban Planning. 2006;77(3):217-226. DOI:10.1016/j.landurbplan.2005.02.010

18. VanWoert ND, Rowe DB, Andresen JA, Rugh CL, Fernandez RT, Xiao L. Green roof stormwater retention: effects of roof surface, slope, and media depth. Journal of Environmental Quality. 2005;34(3):1036-1044. DOI:10.2134/jeq2004.0364

19. Carter TL, Rasmussen TC. Hydrologic behavior of vegetated roofs. Journal of the American Water Resources Association. 2006;42(5):1261-1274. DOI:10.1111/j.17521688.2006.tb05299.x

20. Teemusk A, Mander Ü. Rainwater runoff quantity and quality performance from a greenroof: The effects of short-term events. Ecological Engineering. 2007;30(3):271277. DOI:10.1016/j.ecoleng.2007.01.009

21. Hathaway AM, Hunt WF, Jennings GD. A field study of green roof hydrologic and water quality performance. Transactions of the ASABE. 2008;51(1):37-44.

22. Voyde E, Fassman E, Simcock R. Hydrology of an extensive living roof under subtropical climate conditions in Auckland, New Zealand. Journal of Hydrology. 2010;394(3-4):384-395. DOI:10.1016/j.jhydrol.2010.09.013

23. Stovin V, Vesuviano $\mathrm{G}$, Kasmin $\mathrm{H}$. The hydrological performance of a green roof test bed under UK climatic conditions. Journal of Hydrology. 2012;414-415:148-161. DOI: 10.1016/j.jhydrol.2011.10.022

24. Finnemore EJ, Franzini JB. Fluid mechanics with engineering applications. $10^{\text {th }}$ edition. McGraw Hill: New York; 2009.

25. National Environment Agency (NEA). Weather Statistics. Assessed 11 November 2012.

Available: http://app2.nea.gov.sg/data/cmsresource/20090721544571208250.pdf.

(c) 2012 Qin et al.; This is an Open Access article distributed under the terms of the Creative Commons Attribution License (http://creativecommons.org/licenses/by/3.0), which permits unrestricted use, distribution, and reproduction in any medium, provided the origin al work is properly cited.

\section{Peer-review history:}

The peer review history for this paper can be accessed here: http://www.sciencedomain.org/review-history.php?iid=180\&id=10\&aid=854 